\title{
Evaluation of household's knowledge, attitude, practice on water processing, and diarrhea prevalence in a community
}

\author{
Sofia Sofia ${ }^{1, *}$, Herlina Dimiati ${ }^{2}$, and Nungki Sukma Putri ${ }^{3}$ \\ 1 Department of Environmental Health, Faculty of Medicine, Universitas Syiah Kuala, \\ Teuku Tanah Abee Street, Kopelma Darussalam, Syiah Kuala, Banda Aceh, Aceh, \\ Indonesia 24415 \\ 2 Department of Paediatrics, Faculty of Medicine, Universitas Syiah Kuala, Banda Aceh, \\ Indonesia \\ 3 Graduate Program, Faculty of Medicine, Universitas Syiah Kuala, Banda Aceh, \\ Indonesia \\ *e-mail: sofia_acheh@yahoo.com
}

\begin{abstract}
Diarrhea is an endemic disease in Indonesia and potentially becoming an outbreak. This study aims to describe the relationship between knowledge, attitudes, and practice of heads of households on water processing and prevalence of diarrhea. A cross-sectional survey was applied to 93 heads of households using simple random sampling technique located in Lampulo village, Kuta Alam sub-district, Banda Aceh, Aceh Province in December 2016. Knowledge, attitudes, and practice on water processing and diarrhea prevalence were assessed using questionnaires. Chi-square test was used to analyze a relationship between water source and prevalence of diarrhea. To see a relationship between knowledge, attitude, and practice of heads of households and diarrhea prevalence used Spearman's coefficient correlation ( $\mathrm{CI}=95 \%$; $\alpha=0.05)$. Results showed that water source and prevalence of diarrhea had no statistical relationship $(\mathrm{p}=1.000)$. From 93 households, 32 (34.4 \%) were ever experienced diarrhea and they were used piped water $30(32.26 \%)$ and well water $2(2.15 \%)$ as their sources of drinking water. Relationship of knowledge and diarrhea prevalence has low positive correlation $(r=0.219, p=0.035)$; attitude and diarrhea prevalence have weak positive correlation $(\mathrm{r}=0.326, \mathrm{p}=$ $0.01)$, practice and diarrhea prevalence has weak negative correlation $(\mathrm{r}=-0.256, \mathrm{p}=0.013)$. Knowledge, attitudes, and practice on water processing of the heads of households were correlated to the prevalence of diarrhea.
\end{abstract}

\section{Keywords}

Citation: Sofia, S, Dimiati, H., \& Putri, N. S (2018). Evaluation of household's knowledge, attitude, practice on water processing, and diarrhea prevalence in a community. In F. Jajah \& $\mathrm{H}$. Susilowati (Eds.), UGM Digital Press Health Sciences: Vol. 1. Proceeding of the $2^{\text {nd }}$ International Conference on Health Sciences, (pp. 13-18).

Published: October, 2018 attitude, diarrhea prevalence, knowledge, practice, water processing

\section{Introduction}

Diarrhea remains a public health problem worldwide, especially in developing countries. In Indonesia, diarrheal disease is an endemic 
disease and a potential disease of outbreaks that are often risks of death [1]. Based on data from Republic of Indonesia Ministry of Health, there are 18 outbreaks of diarrhea in 11 provinces, 18 districts, with 1213 people and 30 deaths (Case Fatality Rate $2.47 \%$ ) [2]. As much as 1500000 cases of diarrhea are reported every year in developing countries [3]. Diarrhea is mostly caused by viral, bacterial, and parasitic pathogens [4]. Besides, the other factors that contribute to diarrhea are hygiene and water sanitation. Based on World Health Organization data, clean water supply and environmental health factors contributed to the increase in the incidence of diarrhea [5, 6]. Population needs a reliable and clean water supply to sustain their health. Data from World Health Organization in 2013 showed that $11 \%$ of the world's population had no access to safe drinking water, while $40 \%$ had no proper sanitation. It was also found that annual death from waterborne disease is estimated, at more than three million, such as diarrhea [7]. Unclean and unhealthy environments lead to increase cases of diarrhea and can even lead to the risk of death especially in children [4]. The level of knowledge, attitudes, and practice of head of household on water processing indirectly contribute to preventive and promote efforts in reducing the incidences of diarrhea in the community. Attitude is a reflection of various psychiatric symptoms such as desires, interest, knowledge, emotions, motivation, and willing [8]. In Aceh, there is some research on knowledge, attitudes, and practice regarding diarrhea but issues about diarrhea toward water processing and prevalence of diarrhea were limited [4, 5]. This study aims to describe the relationship between knowledge, attitudes, and practice of head of households on water processing and diarrhea prevalence.

\section{Methods}

\subsection{Study Design and Sampling}

A cross-sectional study was conducted in Lampulo village, Kuta Alam sub-district, Banda Aceh, Aceh Province on December 2016. The selected location is next to the landfill in Banda Aceh Municipality. Households were selected using simple random sampling. Respondents were heads of the selected households.

\subsection{Data Collection}

Interviews were conducted using structured questionnaires which have been tested the validity and reliability. Demographic data of respondents include age and level of education. The incidence of diarrhea was recorded against the head of the family or family members that occurred within the past 1 month. Assessment of knowledge, attitudes, and practice of head of households on water processing and diarrhea prevalence has been evaluated. Level of knowledge was measured by questionnaires that contain questions about the presence of toilets, the distance of water sources with septic tanks, personal hygiene, drinking water treatment, causes of diarrhea, diarrhea symptoms, actions when family members experience diarrhea. The attitude was measured by questionnaires that contain statements of agreeing or disagreeing related to diarrhea, water treatment, diarrhea prevention measures with water treatment and first aid during diarrhea, drinking water sanitation, and environmental health. The Practice was measured using questionnaires that contain statements from activities against drinking water, clean cooking utensils, hygiene and water sanitation, personal hygiene, environmental health, and water treatment. 


\subsection{Data Analysis}

Distribution of frequency was presented for characteristics of respondents, level of knowledge, attitudes, and practice of the heads of households. Spearman's coefficient correlation was used in order to examine the relationship among variables ( $\mathrm{CI}=95 \% ; \alpha=0.05$ ). Chi-square test was also applied to analyze the relationship between water source and prevalence of diarrhea. P value $\leq 0.05$ was considered significant statistically.

\section{Results}

Characteristics of respondents include age group and educational level. The largest age group of heads of households was $20 \mathrm{yr}$ to $30 \mathrm{yr}$ and the lowest was $>40 \mathrm{yr}$. The highest educational level of heads of households was senior high school and the lowest was elementary and undergraduate (Table 1).

Table 1 Characteristics of respondents

\begin{tabular}{ccc}
\hline Characteristics & $\begin{array}{c}\text { Number } \\
\text { (n) }\end{array}$ & $\begin{array}{c}\text { Percentage } \\
\text { (\%) }\end{array}$ \\
\hline Age & & \\
$20-30 \mathrm{yr}$ & 33 & 35.5 \\
$31-40 \mathrm{yr}$ & 31 & 33.3 \\
$>40 \mathrm{yr}$ & 29 & 31.2 \\
Level of education & & \\
Standard & 1 & 1.1 \\
Elementary & 42 & 45.1 \\
High School & 47 & 50.5 \\
Diploma II & 2 & 2.2 \\
Undergraduate & 1 & 1.1 \\
\hline
\end{tabular}

The prevalence of diarrhea in households was presented 32 (34.4\%) and who never had diarrhea 61 (65.6\%). Source of drinking water in the communities recorded had piped water 87 (93.5 \%) more than well water 6 (6.5\%). For people who used piped water they do not do water processing but who use well water, they processed the settling and filtering before consumed. The distribution of frequency of knowledge, attitude, and practice of heads of households toward water processing was shown in Table 2. 
Table 2 Distribution of frequency of knowledge, attitudes, practices on water

\begin{tabular}{ccc}
\hline Variables & $\begin{array}{c}\text { Number } \\
\text { (n) }\end{array}$ & $\begin{array}{c}\text { Percentage } \\
\text { (\%) }\end{array}$ \\
\hline Knowledge & 48 & 51.6 \\
Good & 45 & 48.4 \\
Moderate & 0 & 0 \\
Low & & \\
Attitudes & 81 & 87.1 \\
Agree & 12 & 12.9 \\
Disagree & & \\
Practices & 73 & 78.5 \\
Good & 17 & 18.3 \\
Moderate & 3 & 3.2 \\
Low & & \\
\hline
\end{tabular}

Level of knowledge of heads of households was good 48 (51.6\%) and moderate 45 (48.4\%), attitude of heads of households on water processing were more agree $81(87.1 \%)$ and practice of head of household on water processing were good 73 (78.5\%) and moderate 17 (18.3\%). Relationship of knowledge and diarrhea prevalence was significantly different with low positive correlation ( $r=0.219, p=0.035)$; attitude and diarrhea prevalence was significantly different with weak positive correlation $(r=0.326, p=0.01)$, practice and diarrhea prevalence was significantly different with negatively weak correlation $(r=-0.256$, $\mathrm{p}=0.013$ ). Data for cross-tabulation and correlation between water source and prevalence of diarrhea were showed there had no relationship ( $p=1.000)$ (Table 3$)$.

Table 3 Crosstabulation between water sources and prevalence of diarrhea

\begin{tabular}{llll}
\hline \multirow{2}{*}{ Variables } & \multicolumn{2}{c}{ Frequency (n,\%) } & \multirow{2}{*}{ P value } \\
\cline { 2 - 3 } & Piped water & Well water & \\
\hline Diarrhea & $30(32.26 \%)$ & $2(2.15 \%)$ & \multirow{2}{*}{1.000} \\
No diarrhea & $57(61.29 \%)$ & $4(4.30 \%)$ & \\
\hline
\end{tabular}

\begin{tabular}{lcc}
\hline \multirow{2}{*}{ Variables } & \multicolumn{2}{c}{ Diarrhea Prevalence } \\
\cline { 2 - 3 } & $\mathbf{R}$ & p-value \\
\hline Knowledge & 0.219 & 0.035 \\
Attitude & 0.326 & 0.01 \\
Practice & -0.256 & 0.013 \\
\hline
\end{tabular}

\section{Discussions}

The prevalence of diarrhea in households in Lampulo village, Kuta Alam sub-district, Banda Aceh, Aceh Province was recorded. Republic of Indonesia Ministry of Health stated that some factors causing diarrhea were inadequate to supply and process of clean water, stool contaminated water, and unhygienic stool removal. In addition, factors such as agents, hosts, and practices are also contributing to diarrhea prevalence. Agents that causing diarrhea was often found in water sources, so if this contaminated water used by healthy people it can make people exposed to agents of diarrhea. A Study by Oyat showed that good community-based environmental health services parallel with good personal hygiene could supply the improvement in environmental sanitation and personal hygiene and lead to a reduction in the prevalence of diarrhea [9]. Good water containers should be closed to prevent drinking water contamination. In addition, water sources have to be free from contamination or germs, free from hazardous substances and 
toxic chemicals, and the water is tasteless and odorless [8]. It is also important to consider that shared sanitation was associated with the increased risk of diarrhea. The risks may differ among shared facilities $\leq 5$ households or $\leq 30$ users that make hygiene condition increase [10].

Good knowledge was gained through experience, level of education, confidence, social culture and the source of information that they received. Differences in the level of knowledge can occur due to information obtained from schools, families, neighbors, paramedics, brochures, newspapers, magazines and environment. Respondents with a high level of knowledge tend to have broad insight and easy to receive information from outside. The higher level of education the easier the person receiving information. Results of this study similar to Oyat that explained the association between knowledge of the respondents with the incidence of diarrhea $(p=0.010)$. Good knowledge alone does not enough to change and contribute the improvement of good attitude and good behavior to adopt beneficial personal hygiene practices. It urgently needs to intensify environmental health and personal hygiene awareness with behavior change [9].

Good knowledge will support good behavior so as to support health efforts. Success in prevention and control of diarrheal diseases in the community is the result of good knowledge embodied with prevention activities of the disease. Good knowledge is also able to generate an inner response in the form of attitude towards the object that is known. If someone has a good knowledge it will have a good attitude. Based on the results of this study, people who lived in Lampulo village are full attention and careful on diarrheal diseases. Prevention of diarrhea incidences in the communities can be applied to cleanliness habits, daily water processing before consumption. Source of water in respondents was found the same with the study conducted by Oyat that showed respondents who used piped water had also experienced diarrhea. Availability of water in sufficient quantity within house had been found to be associated with a low prevalence of diarrhea [9]. A person's behavior in the health aspects will have an impact on his health. A person with better behavior in the health will get smaller risk for getting the disease. Positive behavior can reduce the risk of diarrhea.

\section{Conclusions}

This study concluded that the prevalence of diarrheal diseases was correlated with knowledge, attitudes, and practices on water processing. There is a need to improve preventive programs on water processing in order to decrease the prevalence of diarrheal diseases.

Acknowledgments Our special thanks go to respondents who participated in this study.

\section{References}

1. Komarulzaman, A., Smits, J., de Jong, E.: Clean water, sanitation, and diarrhoea in Indonesia: Effects of household and community factors pp. 0-15. [Working Paper]. Nijmegen Center for Economics (NiCE), Institute for Management Research, Radboud University Nijmegen (2014).

2. Kementrian Kesehatan RI.: Profil kesehatan Indonesia [Health Statistic 2015] pp. 179-180. Kemetrian Kesehatan RI, Jakarta (2016). [In Bahasa Indonesia].

3. Teh, N.S.A., Hamid, M.R.A., Asmawi, U.M.M., Nor, N.M.: Food hygiene's knowledge, attitudes, and practices between urban and suburban adolescents. Procedia - Social and Behavioral Sciences 234, 36-44 (2016). doi://doi.org/10.1016/j.sbspro.2016.10.217

4. Nguyen, T.V., Van, P.L., Huy, C.L., Gia, K.N., Weintraub, A.: Etiology and epidemiology of diarrhea in children in Hanoi, Vietnam. International Journal of Infectious Diseases 10(4), 298-308 (2006). doi://doi.org/10.1016/j.sbspro.2016.10.217 
5. Enger, K.S., Nelson, K.L., Rose, J.B., Eisenberg, J.N.S.: The joint effects of efficacy and compliance: A study of household water treatment effectiveness against childhood diarrhea. Water Research 47(3), 1181-1190 (2003). doi://doi.org/10.1016/j.watres.2012.11.034

6. World Health Organization.: Diarrhoeal disease. World Health Organization Website. http://www.who.int/en/news-room/fact-sheets/detail/diarrhoeal-disease. Accessed 30 April 2018.

7. Lomsadze, Z., Makharadze, K., Tsitskishvili, M., Pirtskhalava, R.: Water resources of Kakheti and ecological problems. Annals of Agrarian Science 15(2), 204-208 (2017). doi://doi.org/10.1016/j.aasci.2017.03.002

8. Fattima, E.T., Mutyara, K., Ermaya, Y.S., Setiawati, E.P.: Mother's knowledge, attitude and practice toward safe water usage in Baleendah, Bandung District, West Java from September-October 2012. Althea Medical Journal 2(3), 375-381 (2015).

9. Oyat, F.W.D.: The effects of environmental sanitation and water on diarrhea in children under the age of five years in Misisi compound Lusaka, Zambia: A population based case control study, pp. 19, 59. [Dissertation]. The University of Zambia Lusaka (2007).

10.Baker, K.K., O’Reilly, C.E., Levine, M.M., Kotloff, K.L., Nataro, J.P., Ayers, T.L., Faraq, T.H., et al..: Sanitation and hygiene-specific risk factors for moderate-to-severe diarrhea in young children in the global enteric multicenter study, 2007-2011: Case-control study. PLoS Medicine 13(5), 1-19 (2016). doi://doi.org/10.1371/journal.pmed.1002010 